m40.005

\section{Mechanism of lithium insertion-extraction in metallophosphates with olivine-like structure}

\section{Natalia Bramnik, K. Nikolowski, C. Baehtz ${ }^{\mathrm{a}}$}

Institute for Materials Science, Darmstadt University of Technology, Darmstadt,Germany, ${ }^{a}$ Hasylab/DESY, Hamburg, Germany.E-mail:bramnik@tudarmstadt.de

\section{Keywords: in situ powder diffraction, battery materials, solid-state electrochemistry}

The development and commercialisation of the $\mathrm{LiFePO}_{4}$ cathode for lithium ion batteries provoked the strong interest to the other members of the olivine-like metallophosphates family $\mathrm{Li}_{M} \mathrm{PO}_{4}(M=\mathrm{Mn}, \mathrm{Fe}, \mathrm{Co}, \mathrm{Ni})$. It is well known that lithium extraction from $\mathrm{LiFePO}_{4}$ (triphylite) leads to the formation of the new phase $\mathrm{FePO}_{4}$ (heterosite), which is isostructural to the pristine compound [1]. By the in-situ synchrotron diffraction we studied the structural changes occurring at the delithiation of $\mathrm{LiMn}_{0.6} \mathrm{Fe}_{0.4} \mathrm{PO}_{4}$ and $\mathrm{LiCoPO}_{4}$. The extraction of lithium from $\mathrm{LiMn}_{0.6} \mathrm{Fe}_{0.4} \mathrm{PO}_{4}$ proceeds as a two-step process [2]. The first step (ca. $3.6 \mathrm{~V}$ vs. $\mathrm{Li} / \mathrm{Li}^{+}$) corresponds to the oxidation of iron $\left(\mathrm{Fe}^{2+} / \mathrm{Fe}^{3+}\right)$, the second one (ca. $4.1 \mathrm{~V}$ vs. $\left.\mathrm{Li} / \mathrm{Li}^{+}\right)$to the oxidation of manganese $\left(\mathrm{Mn}^{2+} / \mathrm{Mn}^{3+}\right)$. In contrast to the mechanism earlier reported for this compound [3], both reactions were revealed to proceed in two-phase manner. A solid solution domain seems to exist in the intermediate state, where $\mathrm{Fe}^{3+} / \mathrm{Fe}^{2+}$ electrochemical reaction ends and $\mathrm{Mn}^{3+} / \mathrm{Mn}^{2+}$ begins. All phases appearing during charging the cell have the same olivine-like structure with different cell parameters. The two step character of lithium extraction for $\mathrm{LiCoPO}_{4}$ was observed also and confirmed by XAS measurements $[4,5]$. In in-situ diffraction experiments on $\mathrm{LiCoPO}_{4}$ reveal the formation of lithium-poor olivine-like phase at the earlier stage of charge.

[1] A. Andersson, B. Kalska, L. Häggström, J. Thomas, Solid State Ionic, 2000, 41.

[2] N. Bramnik, K. Bramnik, K. Nikolowski, M. Hinterstein, C. Baehtz, H. Ehrenberg Electrochem. Solid-State Lett, 2005, A379.

[3] A. Yamada, Y. Kudo, K. Liu, J. Electrochem. Soc, 2001, A1153.

[4] N. Bramnik, K. Bramnik, T. Buhrmester, C. Baehtz, H. Ehrenberg, H. Fuess J. Solid State Electrochem, 2004, 558.

[5] M. Nakayama, S. Goto, Y. Uchimoto, M. Wakihara, Y. Kitajima, Chem.Mater, 2004, 3399.

\section{m41.001}

\section{The Structural Diversity of Zincocenes: Half-Sandwich, Slipped-Sandwich and Dimetallocenes Structures}

\section{Ernesto Carmona, Irene Resa and Amor Rodriguez}

Instituto de Investigaciones Quİmicas y Departamento de Quİmica Inorgønica. Univesidad de Sevilla y Consejo Superior de Investigaciones Científicas. Avda. AmĖrico Vespucio, 49. 41092 Sevilla, Spain. E-mail: guzman@us.es

Keywords: zinc compounds, metalloorganic compounds, metal-metal bonds

In contrast to the metallocenes of the transition metals, bis(cyclopentadienyl) derivatives of the nontransition elements may adopt different structures that, in addition to the classical sandwich geometry A (or the analogous distribution of $D_{5 h}$ eclipsed molecular symmetry) enconpass the $\eta^{5} / \eta^{1}$ structures $\mathbf{B}$ and $\mathbf{C}$. The former, or slipped-sandwich geometry, $\eta^{5} / \eta^{1}(\pi)$, is characterized, among other features, by nearly parallel cyclopentadienyl rings, whereas in the latter the monohapto ring is coordinated to the metal in the usual sigma fashion $\left(\eta^{5} / \eta^{1}(\sigma)\right.$ structure).

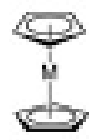

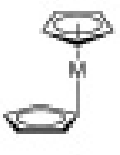

B

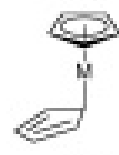

c
In this contribution our structural studies on zincocenes will be discussed. It has been found that while the peralkylated cyclopentadienyl ligands $\mathrm{C}_{5} \mathrm{Me}_{5},{ }^{[1]} \mathrm{C}_{5} \mathrm{Me}_{4} \mathrm{Bu}^{t}$, and others, give rise to $\mathrm{ZnCp}_{2}$ metallocenes of the slipped-sandwich type, $\mathbf{B}$, the silyl-substituted $\mathrm{C}_{5} \mathrm{Me}_{4} \mathrm{SiMe}_{3}$ ligand allows the adoption of the $\eta^{5} / \eta^{1}(\sigma)$ geometry, $\mathbf{C}$. $^{[2]}$ In addition, a unique dizincocene complex $\mathrm{Zn}_{2}\left(\eta^{5}-\mathrm{C}_{5} \mathrm{Me}_{5}\right)_{2}$, has been isolated and shown to consist of two metal-metal bonded $\left(\eta^{5}-\mathrm{C}_{5} \mathrm{Me}_{5}\right) \mathrm{Zn}$ units, with a short $\mathrm{Zn}$ - Zn distance of $2.31 \AA$. $^{[3]}$

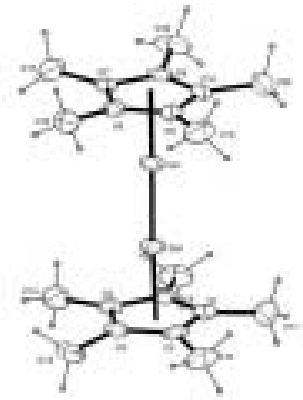

[1] B. Fischer, P. Wijkens, J. Boersma, G. van Koten, W.J.J. Smeets, A.L. Spek, P.H.M. Budzelaar, J. Organomet. Chem., 1989, 376, 223-233.

[2] R. Fenøndez, I. Resa, D. del RÌo, E. Carmona. Organomet., 2003, $22,381$.

[3] I. Resa, E. Carmona, E. Gutierrez-Puebla, A. Monge. Science, 2004, 305, 1136 